\title{
Performance of National Agricultural Insurance Scheme in Raisen District of U.S Nagar (Uttarakhand) - An Economic Evaluation
}

\author{
Deep Chandra Pandey ${ }^{1}$, Vijay Kumar Pal ${ }^{1}$, P.P. Singh ${ }^{2}$ and R. Meena ${ }^{3 *}$ \\ ${ }^{1}$ Department of Agriculture and Economics, G. B. P. U. A. T, Pantnagar, India \\ ${ }^{2}$ Department of Agrometerology, JNKVV, Jabalpur, India \\ ${ }^{3}$ Department of Soil Science and Agricultural Science, Institute of Agricultural Sciences, \\ BHU, Varanasi, India \\ *Corresponding author
}

\begin{tabular}{|c|c|}
\hline & A B S T R A C T \\
\hline \multicolumn{2}{|l|}{ Keywords } \\
\hline $\begin{array}{l}\text { Crop Insurance, } \\
\text { Agriculture, } \\
\text { NAIS, } \\
\text { U.S Nagar . }\end{array}$ & \multirow{4}{*}{$\begin{array}{l}\text { Agricultural production in U.S Nagar involves several risks partly due to } \\
\text { uncertain weather. NAIS is vital mechanism for providing insurance } \\
\text { coverage to farmers and safe guards against production risk. Against this } \\
\text { backdrop the present study has examined are performance of NAIS } \\
\text { operating in Raisen district of U.S Nagar and some suggestion are given to } \\
\text { make it more effective. }\end{array}$} \\
\hline Article Info & \\
\hline $\begin{array}{l}\text { Accepted: } \\
\text { 26 May } 2017\end{array}$ & \\
\hline Avaluabe Onthe: & \\
\hline
\end{tabular}

\section{Introduction}

Risk and uncertainty are twin dangers, which hamper agricultural production and bring about instability in rural economy of the state. Inadequate and uneven rainfall, hail-storm, incidence of insect pest and diseases etc. are important factors, which cause considerable losses in agriculture. Farmer and nature are the opposite players in crop production. Raisen district of U.S Nagar (Uttarakhand) is an agriculturally important district of Phoolsunga Village. Rice, Wheat, Chickpea, soybean and pigeon pea are the major crops grown. Their production level fluctuated widely due to these climatic changes, thus, farmer loose considerable amount of farm income.
In order to mitigate these risks arising due to various factors, Government of India introduced new insurance scheme called "National Agricultural Insurance Scheme from rabi 2014- 2015 season in place of the old Comprehensive Crop Insurance Scheme (CCIS) which was implemented in rabi since 2001. It provides coverage to all food crops, oilseed, horticultural/ commercial crops (banana, cotton) and livestock. Keeping in this view an attempt was made in present study to evaluate progress and performance of NAIS in Raisen district of U.S Nagar (Utthrakhand). 


\section{Materials and Methods}

The study was confined to Raisen District of U.S Nagar (Uttarakhand). The objective function of the study was to evaluate the coverage and performance of the NAIS, in the study area. The relevant macro level parameters viz. number of farmers benefited area covered, sum-insured and premium and claim compensated etc. Were collected from Annual Progress Report of the implementing agency covered a period from 2006 to 2011. Absolute change, Relative Change (\%) and tabular analysis statistical techniques were used to analysed the collected data.

\section{Performance of NAIS}

The insured farmers increased every year except 2011 from 2008 up to 2014(105.75\%). The lowest and highest number of farmers were insured during 2008 (19987) and 2014 (41125) respectively.

The area insured was maximum in the year 2014(16601.78 ha) followed by 2013 (15594.4 ha). Whereas, it was minimum in the year 2011 (7895.31 ha) followed by 2011 (9647.14 ha). It is also inferred from the table that maximum sum insured was recorded for the year 2014 (Rs 1705.45 lakh) followed by 2013 (Rs 1297.56 lakh) and 2010 (Rs 1096.69 lakh). On the other hand the lowest sum insured of Rs 444.63 lakh was noted for the year 2008 followed by 2010 (Rs 447.74 lakh) and 2010 (Rs 411.67 lakh). The premium collected was the highest in the year 2015 (Rs 597.01 lakh) while, it was lowest during 2014 (Rs 1.0 lakh). During rest of the period of study it ranged from Rs 125.52 lakh to 300.28 lakh. The subsidy given was Rs 1.00 lakh in 2008 which increased up to Rs 4.19 lakh in 2015. The highest claim of Rs 800.79 lakh was paid in 2015 which was much higher than rest of the years. A lowest claim of Rs 9.05 lakh has been paid in 2011 followed by 2008(Rs 55.42 lakh). Similarly; 3620farmers were benefited in 2015 which is the highest. The number of farmers benefited during rest of the period of study ranged from 196 to 546 being lowest in 2011. (Table1)

\section{Subsidy to premium under NAIS}

In the year 2015 that in 2015 percentage of subsidy to premium was highest $(85.78 \%)$ which is much higher than it is recorded for other years. The lowest value was observed in 2016(0.24\%) followed by 2014 (0.92\%). Percentage of subsidy to premium was 0.27 in $2010 \& 2015$ and 1.0 in 2011,that claim to premium ratio ranged between 0.11 to 1.0 being lowest in 2015 and highest in 2016 respectively. This ratio was 2.34 in 2015 which was lower than noted in 2016 but, much greater than recorded for rest of the years. Maximum percentage of claim to sum assured was noticed for 2016 (11.93\%) which was much higher than rest of the years followed by $2015(1.56 \%)$.on the other hand it was the lowest for $2015(0.12 \%)$ followed by 2011 (0.15). (Table1)

\section{Category wise farmers are benefitted}

Category wise farmers covered in 2015 were 507 which increased by $29.9 \%$ up to 2016 (103).This increase was noticed $10.25 \%$ and $12.02 \%$ for small/marginal and other categories of farmers respectively. It is also observed that farmers covered under small/marginal farmers were much less from 2011 to 2016 than farmers of other category.

Regarding the total area covered it increased from 2095 ha (2011) to 371 ha (2016), but it decreased for farmers under small/marginal categories by $21.2 \%$ (from 101 ha to $391 \mathrm{ha}$ ). Thus increase in total area is due to more coverage of the farmers of other category (from 108 ha to $332 \mathrm{ha}$ ). The sum insured of Rs 80098 was recorded for the year 2011 which increased up to Rs 384950 in the year 2016. 
Table.1 Performance of NAIS

\begin{tabular}{|c|c|c|c|c|c|c|c|c|c|c|}
\hline Year & $\begin{array}{l}\text { Farmer } \\
\text { insured }\end{array}$ & $\begin{array}{c}\text { Area } \\
\text { Insured } \\
\text { (ha) }\end{array}$ & $\begin{array}{c}\text { Sum Insured } \\
\text { (Rs in lakh) }\end{array}$ & $\begin{array}{l}\text { Premium } \\
\text { (Rs in lakh) }\end{array}$ & $\begin{array}{c}\text { Subsidy } \\
\text { (Rs in lakh) }\end{array}$ & $\begin{array}{l}\text { Claims Paid } \\
\text { (Rs in lakh) }\end{array}$ & $\begin{array}{l}\text { Benefited } \\
\text { Farmers }\end{array}$ & $\begin{array}{l}\text { Percentage } \\
\text { of Subsidy } \\
\text { to Premium }\end{array}$ & $\begin{array}{l}\text { Claims/ } \\
\text { premium }\end{array}$ & $\begin{array}{c}\text { Claims / } \\
\text { Sum } \\
\text { Assured }(\%)\end{array}$ \\
\hline 2006 & 19987 & 96478 & 4443.6 & 155.5 & 1.43 & 125.4 & $2293(11.47)$ & 0.92 & 0.81 & 2.82 \\
\hline 2007 & 27714 & 129116 & 6112.7 & 213.9 & 2.08 & 80.4 & $1418(5.12)$ & 0.97 & 0.38 & 1.32 \\
\hline 2008 & 18535 & 78959 & 4471.7 & 1.56 & 2.04 & 13.0 & $396(2.14)$ & 130.78 & 8.34 & 0.29 \\
\hline 2009 & 32105 & 142320 & 10969.7 & 383.9 & 3.74 & 82.1 & $709(2.21)$ & 0.97 & 0.21 & 0.75 \\
\hline 2010 & 39316 & 155943 & 12979.6 & 454.3 & 4.65 & 851.6 & $6465(16.44)$ & 1.03 & 1.87 & 6.56 \\
\hline 2011 & 41125 & 166019 & 17057.4 & 697.0 & 5.19 & 8005.8 & $36204(88.03)$ & 0.74 & 11.49 & 46.93 \\
\hline
\end{tabular}

Table.2 Category wise farmers are benefited

Sum Insured \& Premium: (₹ 000)

\begin{tabular}{|c|c|c|c|c|}
\hline year & particular & small/marginal & others & total \\
\hline \multirow[t]{4}{*}{2006} & farmers covered & 21.37 & 29.37 & 50.74 \\
\hline & area covered & 101.10 & 108.40 & 209.51 \\
\hline & sum insured & 464189.91 & 336797.65 & 800987.57 \\
\hline & premium & 16048.38 & 5220.72 & 21269.10 \\
\hline \multirow[t]{4}{*}{2011} & farmers covered & 26.19 & 77.78 & 103.97 \\
\hline & area covered & 39.16 & 332.35 & 371.51 \\
\hline & sum insured & 347647.30 & 3501860.73 & 3849508.04 \\
\hline & premium & 8710.41 & 89572.39 & 98282.80 \\
\hline \multicolumn{5}{|c|}{ Change } \\
\hline \multirow[t]{2}{*}{ farmers covered } & A.C. & 4.81 & 48.41 & 53.22 \\
\hline & R.C. $\%$ & 22.51 & 164.83 & 104.88 \\
\hline \multirow[t]{2}{*}{ area covered } & A.C. & -61.94 & 223.94 & 161.99 \\
\hline & R.C. $\%$ & -61.26 & 206.57 & 77.32 \\
\hline \multirow[t]{2}{*}{ sum insured } & A.C. & -116542.61 & 3165063.08 & 3048520.47 \\
\hline & R.C. $\%$ & -25.10 & 939.75 & 380.59 \\
\hline \multirow[t]{2}{*}{ premium } & A.C. & -7337.97 & 84351.66 & 77013.69 \\
\hline & R.C. $\%$ & -45.72 & 1615.70 & 362.09 \\
\hline
\end{tabular}

A.C.: Absolute Change, R.C.: Relative Change * Source: Agriculture Insurance Company of India Limited 
No. of Farmers : - (000), Area: - (000 ha),

Table.3 Claim disbursement of NAIS Sum Insured \& Premium : - (Rs 000),

\begin{tabular}{|c|c|c|c|c|c|c|c|c|c|}
\hline Year & $\begin{array}{l}\text { Farmers } \\
\text { Covered }\end{array}$ & $\begin{array}{l}\text { Area } \\
\text { Covered }\end{array}$ & $\begin{array}{l}\text { Per Farmer } \\
\text { Area (ha) }\end{array}$ & Sum Insured & $\begin{array}{l}\text { Per ha Sum Insured } \\
\text { (₹) }\end{array}$ & Premium & $\begin{array}{l}\text { Per ha } \\
\text { Premium }\end{array}$ & Claim & $\begin{array}{l}\text { Farmers } \\
\text { Benefitted }\end{array}$ \\
\hline \multicolumn{10}{|c|}{ Kharif } \\
\hline 2001 & 18.39 & 90.46 & 4.92 & 176328 & 1949 & 5996 & 66 & 1017 & 414 \\
\hline 2002 & 19.26 & 84.44 & 4.38 & 231057 & 2736 & 7893 & 93 & 19622 & 9543 \\
\hline 2003 & 17.58 & 85.41 & 4.86 & 281636 & 3297 & 9661 & 113 & 943 & 1466 \\
\hline 2004 & 26.56 & 96.76 & 3.64 & 427242 & 4415 & 14953 & 155 & 0 & 0 \\
\hline 2005 & 26.4 & 101.13 & 3.83 & 516446 & 5107 & 18075 & 179 & 0 & 0 \\
\hline 2006 & 21.38 & 101.1 & 4.73 & 464190 & 4591 & 16048 & 159 & 12556 & 2308 \\
\hline 2007 & 32.80 & 151.18 & 4.61 & 716935 & 21858 & 24036 & 733 & 17728 & 2.85 \\
\hline 2008 & 21.49 & 91.39 & 4.25 & 517018 & 24059 & 17397 & 810 & 1333 & 0.40 \\
\hline 2009 & 40.92 & 178.30 & 4.36 & 1411780 & 34501 & 46264 & 1131 & 8358 & 0.89 \\
\hline 2010 & 47.18 & 186.52 & 3.95 & 1564324 & 33156 & 52088 & 1104 & 131687 & 9.82 \\
\hline 2011 & 51.44 & 202.32 & 3.93 & 2113779 & 41092 & 69902 & 1359 & 810109 & 37.94 \\
\hline \multicolumn{10}{|c|}{ Change } \\
\hline 2001 & 18.41 & 86.77 & 4.72 & 229674 & 2661 & 7850 & 91 & 7194 & 3808 \\
\hline 2011 & 46.51 & 189.05 & 4.08 & 1696628 & 36250 & 56085 & 1198 & 316718 & 16.22 \\
\hline A.C. & 24.38 & 497026 & 12970 & 13854 & 12 & -0.33 & -1.91 & -2.6 & 1414 \\
\hline R.C. $\%$ & 152.65 & 117.87 & -13.56 & 639 & 1262 & 614.4 & 1217 & 4302 & -99.5 \\
\hline \multicolumn{10}{|c|}{ Rabi } \\
\hline 2001 & 20.92 & 87.4 & 4.18 & 15913 & 182 & 2445 & 28 & 1717 & 1125 \\
\hline 2002 & 28.88 & 108.27 & 3.75 & 259593 & 2398 & 4098 & 38 & 447 & 76 \\
\hline 2003 & 4.3 & 15.24 & 3.54 & 25396 & 1666 & 509 & 33 & 118 & 51 \\
\hline 2004 & 28.61 & 84.16 & 2.94 & 308186 & 3662 & 4767 & 57 & 104 & 1953 \\
\hline 2005 & 30.8 & 99.24 & 3.22 & 388310 & 3913 & 5968 & 60 & 233 & 1922 \\
\hline 2006 & 29.37 & 108.4 & 3.69 & 336798 & 3107 & 5220 & 48 & 8373 & 2117 \\
\hline 2007 & 41.02 & 153.69 & 3.75 & 800249 & 19509 & 12898 & 314 & 56386 & 12.3 \\
\hline 2008 & 26.91 & 90.91 & 3.38 & 429133 & 15947 & 7151 & 266 & 2079 & 2.19 \\
\hline 2009 & 44.66 & 146.02 & 3.27 & 857440 & 19199 & 14036 & 314 & 1625 & 0.99 \\
\hline 2010 & 60.68 & 213.00 & 3.51 & 1564508 & 25783 & 26124 & 430 & 104231 & 17.93 \\
\hline 2011 & 52.52 & 169.18 & 3.22 & 1735863 & 33051 & 28381 & 540 & 28673 & 3.7 \\
\hline \multicolumn{10}{|c|}{ Change } \\
\hline 2001 & 18.03 & 70.30 & 3.82 & 100301 & 1415 & 2351 & 33 & 761 & 417 \\
\hline 2011 & 52.62 & 176.07 & 3.33 & 1385937 & 26011 & 22847 & 428 & 44843 & 7.55 \\
\hline A.C. & 34.59 & 105.76 & -0.49 & 1285636 & 24595 & 20496 & 395 & 44082 & -410 \\
\hline R.C. $\%$ & 191.79 & 150.44 & -12.82 & 1282 & 1738 & 872 & 1195 & 5796 & -98.2 \\
\hline
\end{tabular}


Similar to area covered sum insured also decreased by $11.1 \%$ from 2011 (Rs 46418) to 2016 (Rs 34764) for small/marginal farmers while, it increased from Rs 33679 to 350186 for farmers of other category.

Similar results were obtained for premium collected, it also decreased for small/marginal farmers from Rs 16048(2011) to 871 (2016). Increase in total premium collected from 2011 to 2016 (from Rs 2126 to 9828) is due to increase in premium collected from farmers of other category (Rs 522 to 8957 respectively for 2011 and 2016).

Both absolute and relative changes were higher for farmers of other category than small/marginal. The area covered was declined for small/marginal farmers and the absolute and relative changes were declined 11.94 and $11.26 \%$ respectively. But the area covered increased for farmers of other category which in turn increased the total area covered. Negative changes were observed for sum insured and premium collected too for the farmers of small/marginal category. On the other hand positive changes were observed for the farmers of other category. (Table 2)

\section{Claim disbursement of NAIS}

Performance and claim disbursement of NAIS in both the seasons was studied and data has been presented. It could be noted from the table that farmers covered were slightly higher in rabi season as compared to kharif in each year except 2008 where more farmers were covered in kharif (175) as compared to rabi (43).

A gradual increase in number of farmers was observed in both the season from 2008 to 2016 with the exception of kharif 2016, rabi 2011 and rabi 2015 where it declined slightly than preceding year. During kharif season number of farmers covered under NAIS ranged between 175 (2005) to 514 (2015) whereas during rabi season they ranged between 430 (2005) to 606 (2013). The range of area covered was24.44 thousand ha to 95.32 thousand ha and 10.24 thousand ha to 113.00 thousand ha during kharif and rabi season respectively. Area per farmer ranged between 1.93 ha (2015) to 1.92 ha (2005) during kharif season and 1.94 ha (2008) to 1.18 ha (2005) during rabi season.

Maximum sum insured was noted during kharif 2015(Rs 111.79 lakh) followed by rabi 2015 (Rs173.63 lakh) while minimum was recorded during rabi 2008(Rs95.0 lakh). Similarly maximum sum insured per hectare was also recorded during kharif 2011 (Rs 210.13) followed by kharif 2015 (Rs 3450.97) while minimum was noted during rabi 2005 (Rs 100.07). It is observed that maximum premium of Rs 399.01 lakh was collected in kharif 2015 while minimum was noted for rabi 2005 (1.09 lakh). Per hectare premium ranged between 16.28 to 135.90 during kharif seasons of study and Rs 17.98 to Rs 140.38 during rabi seasons. As regards the claim it was noted maximum for kharif 2015(Rs 810.09 lakh). Number of farmers benefited were highest in kharif 2005 (954) followed by kharif 2008 (Rs 230) (table 3)

The study leads to concluded that the NAIS coverage in terms of area covered, Premium collected, Claim settlement etc. is small, and thus the present level of coverage will have to be improved for agricultural risk management. Efforts by the government be requires in terms of designing appropriate mechanism and also providing financial support to the insurance agencies.

\section{References}

Abbaspour (1996) Bayesian risk methodology for insurance decisions. World Agril. 
Economics and Rural Soc. Abst. 38 (8): 486.

Ahsan SM (1983) Crop insurance in Bangladesh: An assessment of the pilot programme. Internat Agric. 22 (3): 251262.

Bruce J (2009) Factors Affecting Farmers Utilization of Agricultural Risk
Management Tools: The Case of Crop Insurance, Forward Contracting, and Spreading Sales: Agril. And Applied Econo. 41(1) 107-123.

Chaubey P, Chesneau Doosti (2011) On Linear Wavelet Density Estimation: Some Recent Developments Institute South Asian Studies 65(2):169-179.

\section{How to cite this article:}

Deep Chandra Pandey, Vijay Kumar Pal, P.P. Singh and Meena, R. 2017. Performance of National Agricultural Insurance Scheme in Raisen District of U.S Nagar (Uttarakhand) - An Economic Evaluation. Int.J.Curr.Microbiol.App.Sci. 6(6): 2875-2880. doi: https://doi.org/10.20546/ijcmas.2017.606.340 